\title{
IDENTIFIKASI KEGAGALAN STRUKTUR DAN ALTERNATIF PERBAIKAN SERTA PERKUATAN GEDUNG BPKP PROVINSI SUMATERA BARAT
}

\author{
Febrin Anas Ismail ${ }^{1}$
}

\begin{abstract}
ABSTRAK
Pada gempa 30 September 2009 Gedung BPKP Provinsi Sumatera Barat mengalami kerusakan struktur yang cukup berat. Penelitian ini bertujuan untuk mengidentifikasi kerusakan yang terjadi pada gedung BPKP, baik secara visual maupun menggunakan software analisa struktur. Dari hasil analisa yang dilakukan, terlihat kerusakan struktur pada Gedung BPKP terutama diakibatkan oleh kurangnya kapasitas lentur kolom dalam menahan gaya lateral yang terjadi. Hal ini ditandai dengan adanya retak yang terjadi pada ujung kolom. Kerusakan non-struktural pada Gedung BPKP disebabkan oleh tidak adanya ikatan antara dinding bata dengan struktur bangunan, terlihat dengan tidak adanya pengangkuran yang baik dari struktur kolom ke dinding bata. Tegangan geser yang terjadi pada dinding bata juga melebihi tegangan yang diizinkan. Alternatif perbaikan yang bisa dilakukan seperti metoda injeksi, metoda grouting maupun perbaikan kolom yang telah mengalami kerusakan berat dengan penggantian tulangan dan beton yang mengalami kerusakan. Penambahan dinding geser maupun perkuatan kolom dengan metode jacketing pada gedung BPKP cukup efektif untuk perkuatan strukturnya, hal tersebut terlihat dengan adanya penurunan yang cukup signifikan dari gaya dalam dan perpindahan pada kolom jika dibandingkan dengan kondisi eksisting.
\end{abstract}

Kata Kunci : struktur, kapasitas lentur, gaya lateral, tegangan geser, metode injeksi, metode grouting, dinding geser, jacketing

\section{PENDAHULUAN}

Gedung Kantor Badan Pengawasan Keuangan dan Pembangunan (BPKP) Provinsi Sumatera Barat merupakan bangunan gedung berlantai 5 (lima) dengan luas total bangunan $4000 \mathrm{~m}^{2}$, dan terletak di jalan Rasuna Said No. 69 Padang. Gedung ini dibangun pada tahun 2006 dengan struktur gedung yang merupakan portal beton bertulang dan selesai dibangun pada tahun 2008.

Pada gempa 30 September 2009 gedung BPKP yang baru beroperasi setahun setelah dibangun juga mengalami kerusakan yang cukup parah. Kerusakan terjadi pada beberapa bagian dan diindikasikan mengalami kerusakan struktur yang signifikan. Hal ini menyebabkan operasional gedung ini dihentikan dan aktifitas BPKP dipindahkan ke gedung lain.

Kerusakan gedung BPKP yang dapat diamati secara visual seperti lepasnya sambungan balok dan kolom dan ditemukan beberapa bagian dinding yang terlepas. Hal ini sangat membahayakan bagi kegiatan karyawan BPKP. Dalam buku Pedoman Perencanaan Ketahanan Gempa Untuk Rumah Dan Gedung (Departemen Pekerjaan Umum, 1987) disebutkan bahwa gedung-gedung monumental atau gedung-gedung yang diperuntukkan bagi fasilitas umum harus tetap berfungsi setelah gempa terjadi, namun hal ini tidak terjadi pada gedung BPKP. Dari kerusakan yang terjadi pada gedung tersebut penulis tetarik untuk meneliti penyebab terjadinya kerusakan struktur dan menganalisa kemungkinan gedung ini dapat dioperasikan kembali setelah kerusakan yang terjadi diperbaiki, terutama kerusakan strukturnya.

${ }^{1}$ Dosen Jurusan Teknik Sipil Universitas Andalas, febrin@ft.unand.ac.id 


\section{PEMBAHASAN}

Bangunan gedung BPKP berlokasi di Jalan Rasuna Said No. 69 Padang. Struktur utama gedung terdiri atas 5 (lima) lantai, menggunakan sistem struktur rangka beton yang terdiri atas elemen kolom, balok dan pelat lantai. Secara umum gambaran eksisting gedung BPKP adalah sebagai berikut :

1. Denah Struktur Gedung BPKP secara umum merupakan struktur yang simetris dan balok serta kolom yang seragam dengan adanya tonjolan pada bagian kiri dan kanan gedung yang juga simetris.

2. Dari segi fungsional gedung diperuntukkan sebagai bangunan kantor.

3. Kolom utama terdiri atas kolom persegi $600 \mathrm{~mm}$ x $600 \mathrm{~mm}$, dengan jumlah tulangan utama adalah 16D16 dan sengkang $\phi 10-100$ pada bagian $1 / 4 \mathrm{~h}$ kolom atas dan bawah serta $\phi 10-150$ pada bagian $\mathrm{h} / 2$.

\subsection{Evaluasi Kerusakan Gedung}

Dari hasil pengamatan visual di lapangan, secara umum kerusakan yang terjadi dapat dikelompokkan dalam 2 kategori, yaitu :

1. Kerusakan elemen struktural terjadi pada kolom lantai $1 \mathrm{~s} / \mathrm{d}$ lantai 5 yang mengalami kehancuran pada ujung-ujung kolom serta terlepasnya selimut beton.

2. Kerusakan elemen non-struktural seperti dinding, partisi, plafond dan elemen non-struktural penunjang fungsi gedung lainnya.

\section{a. Evaluasi Kerusakan Struktural Bangunan}

Dari hasil pengamatan lapangan, diperoleh :

1. Kerusakan struktur pada lantai 2 :

Adanya kerusakan pada kaki kolom berupa selimut beton kolom terlepas dan beton struktur kaki kolom hancur. Pada joint balok yang sama juga terjadi rusak ringan dengan lepasnya selimut beton.

2. Kerusakan struktur pada lantai 3 dan lantai 4 :

a. Kerusakan struktur gedung BPKP lebih terkonsentrasi pada kerusakan kolom. Kegagalan struktur pada ujung bagian kolom berupa terlepasnya selimut beton dan ikatan sengkang.

b. Lepasnya sambungan balok ke kolom yang terjadi di lantai 3

3. Kerusakan joint balok-kolom pada lantai 4.

\section{b. Evaluasi Kerusakan Non-Struktural}

Kerusakan non-struktural pada gedung BPKP secara substansial lebih diakibatkan karena tidak adanya ikatan yang terjadi pada dinding bata. Dinding ini tidak terkait dengan struktur bangunan sehingga banyak yang jatuh keluar.

Kerusakan elemen non-struktural bangunan, seperti :

1. Dinding Terlepasnya dinding bagian luar pada beberapa bidang terjadi akibat tidak adanya balok dan kolom praktis sebagai pengaku pada dinding tersebut.

2. Plafond

Kerusakan plafond terjadi karena adanya kerusakan pada struktur atau kerusakan elemen non-struktur lainnya disekitar plafond tersebut.

3. Pintu dan jendela

Pecah dan terlepasnya kaca pada beberapa bagian jendela dan pintu gedung.

\section{2 | J URNAL REKAYASA SIPIL}




\subsection{Evaluasi Kemiringan Bangunan}

Evaluasi kemiringan bangunan dilakukan dengan mengukur kemiringan bangunan terhadap sumbu vertikal (vertikality) dan horizontal (horizontality) dengan menggunakan alat ukur Theodolit. Dari data yang diperoleh terlihat bahwa kemiringan maksimum yaitu sebesar $1,2 \mathrm{~cm}$ arah sumbu $\mathrm{x}$ ( ke arah utara dari bangunan) dan juga terjadi kemiringan sebesar $1.99 \mathrm{~cm}$ arah sumbu y (ke arah timur dari bangunan), dimana masih dalam batas kemiringan yang diizinkan sebesar $15 \mathrm{~cm}$ untuk bangunan 5 tingkat, sesuai dengan syarat kinerja batas layan struktur gedung pada Standar Perencanaan Ketahanan Gempa Untuk Struktur Bangunan Gedung SNI-1726-2002.

\subsection{Evaluasi Kualitas Mutu Beton dengan Hammer Test}

Dari hasil pengujian Hammer Test yang telah dilakukan pada sejumlah elemen struktur kolom dan balok, diperoleh mutu beton (fc') untuk kolom berkisar antara $300 \mathrm{~kg} / \mathrm{cm}^{2}-350 \mathrm{~kg} / \mathrm{cm}^{2}$ (K-300). Dapat disimpulkan bahwa kualitas mutu beton yang ada dari elemen kolom masih dalam kondisi baik dan memenuhi persyaratan.

\subsection{Pemodelan Struktur}

Pemodelan struktur Gedung BPKP berujuan untuk menganalisis penyebab kerusakan komponen struktur gedung, baik itu pada balok, kolom, maupun pada dinding gedung. Pada pemodelan struktur yang dilakukan dengan menggunakan SAP 2000, selain elemen balok, kolom dan pelat lantai, dinding dianggap memberikan sumbangan kekakuan dan kekuatan pada struktur secara keseluruhan (Gambar 1.). Dari hasil analisa, diperoleh gambaran lokasi tegangan maksimum yang terjadi pada dinding akibat beban gempa dan dibandingkan dengan lokasi kerusakan akibat gempa yang terjadi.

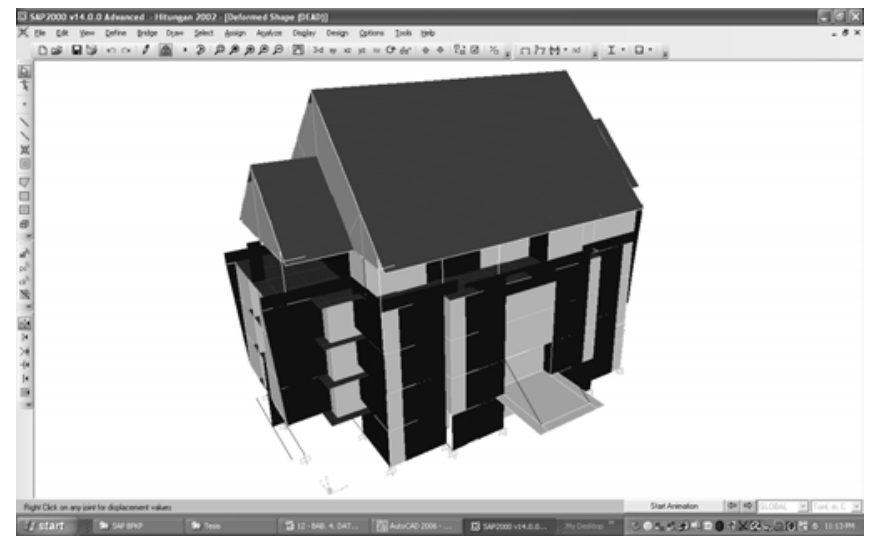

Gambar 1. Pemodelan Struktur Dengan SAP 2000

\subsection{Pembebanan Struktur}

Pembebanan gedung didasarkan pada Peraturan Pembebanan Indonesia Untuk Gedung Tahun 1983. Beban yang bekerja pada struktur terdiri atas beban gravitasi yang merupakan beban hidup dan beban mati.

a. Beban mati :

- Berat sendiri beton

- Baja

- Keramik lantai/cm tebal

$: 2500 \mathrm{~kg} / \mathrm{m}^{3}$

- Spesi

: $7850 \mathrm{~kg} / \mathrm{m}^{3}$

: $21 \mathrm{~kg} / \mathrm{m}^{2}$ (asumsi tebal $2 \mathrm{~cm}$ )

: $20 \mathrm{~kg} / \mathrm{m}^{2}$ (asumsi tebal $2 \mathrm{~cm}$ )

VOLUME 7 NO.2, OKTOBER 2011 


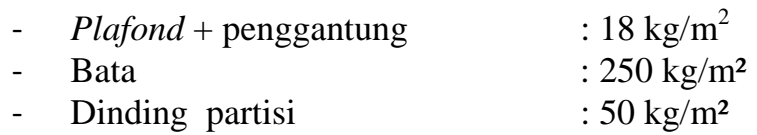

b. Beban hidup yang bekerja adalah sesuai dengan fungsi gedung sebagai bangunan perkantoran dengan beban hidup sebesar $250 \mathrm{~kg} / \mathrm{m} 2$ pada ruangan yang berfungsi sebagai perkantoran.

c. Pada hitungan strukturnya beban mati yang diinputkan pada SAP 2000 (Dewobroto, 2006) adalah beban mati tambahan akibat keramik lantai, spesi dan plafond sedangkan beban mati akibat berat sendiri struktur seperti berat balok, kolom dan dinding bata dihitung secara otomatis oleh SAP 2000

d. Beban mati tambahan akibat ubin, spesi dan plafond di perkirakan maksimal $150 \mathrm{~kg} / \mathrm{cm} 2$.

e. Beban mati tambahan dan beban hidup seperti diatas diinputkan sebagai beban "uniform area" pada elemen lantai struktur.

\subsection{Kombinasi Pembebaan}

Kombinasi pembebanan mengacu standar kombinasi pembebanan mengacu standar SNI 03-2847 2002 (Tata Cara Perencanaan Struktur Beton untuk Bangunan Gedung), yaitu :

1. $1,2 \mathrm{DL}+1,6 \mathrm{LL}$

2. 1,2DL + LL + Ex + 0,3Ey

3. 1,2DL + LL + Ex - 0,3Ey

4. 1,2DL + LL - Ex + 0,3Ey

5. 1,2DL + LL - Ex - 0,3Ey

6. 1,2DL + LL + 0.3Ex + Ey

7. 1,2DL + LL + 0.3Ex - Ey

8. 1,2DL + LL - 0.3Ex + Ey

9. 1,2DL + LL - 0.3Ex - Ey

Dimana :

DL (Dead Load) $\quad$ : Beban mati

LL (Life Load) : Beban hidup

Ex (Earthquake arah $x)$ : Gempa arah sumbu $\mathrm{x}$

Ey (Earthquake arah y) : Gempa arah sumbu y

\subsection{Analisa Ragam Respon Spektrum}

Spektrum respon gempa rencana yang digunakan adalah gempa dengan probabilitas terlampaui $10 \%$ dalam 50 tahun atau gempa dengan periode ulang 500 tahun pada Peta Hazard Gempa Indonesia 2010 untuk wilayah padang dengan Percepatan Puncak Muka Tanah, PGA sebesar 0,44g (Badan Penelitian dan Pengembangan Kementrian Pekerjaan Umum, 2010).

\subsection{Analisa Kapasitas Penampang}

Dari hasil analisa struktur akan diketahui kapasitas penampang dari elemen strukturnya seperti momen nominal balok, geser balok, diagram interaksi kolom serta kapasitas geser kolom. Dari hasil kapasitas penampang ini akan diketahui apakah penampang tersebut mampu menahan beban yang bekerja, baik kombinasi benan hidup dan beban mati maupun beban gempa, sehingga akan diperoleh penyebab dari kerusakan struktur gedung tersebut.

\section{4 | J URNAL REKAYASA SIPIL}




\subsection{Kapasitas Penampang Balok}

Analisa penampang balok dilakukan untuk mengetahui kapasitas momen penampang masingmasing elemen balok dan dibanding momen luar yang terjadi, sehingga diketahui kemampuan dari masing-masing elemen balok tersebut. Pada Tabel 1. terlihat perbandingan tulangan terpasang dengan analisa ulang perhitungan tulangan.

\subsection{Kapasitas Lentur Penampang Kolom}

Diagram interaksi adalah diagram yang menggambarkan kemampuan atau kapasitas penampang kolom. Diagram interaksi pada kolom digambarkan oleh grafik hubungan antara momen dan aksial kolom. Diagram interaksi kolom internal lantai 3 dengan dimensi 60 x $60 \mathrm{~cm}$ adalah sebagaimana dapat dilihat pada Gambar 2.

\subsection{Kapasitas Geser Penampang Kolom}

Kapasitas geser kolom ditentukan oleh diameter dan jarak tulangan geser terpasang (sengkang/begel), untuk gedung BPKP Provinsi Sumatera Barat kapasitas geser untuk masingmasing tipe kolom seperti pada Tabel 2.

Tabel 1. Kapasitas Lentur Balok Eksisting 


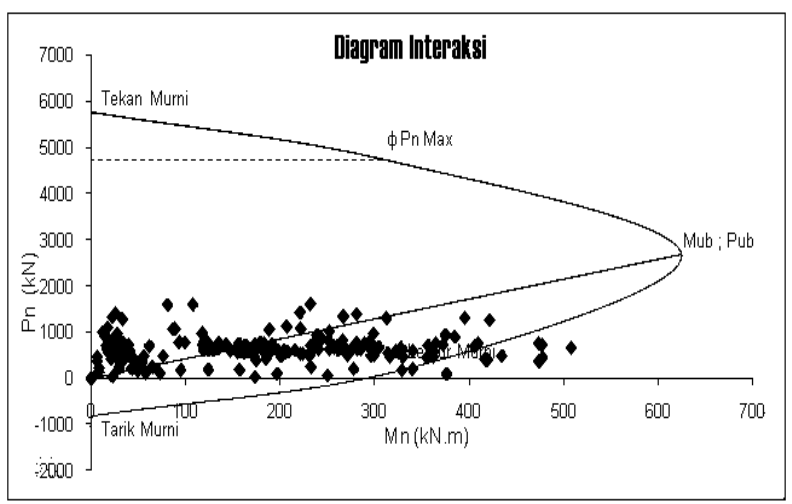

Gambar 2. Diagram Interaksi Kolom Internal Lantai 3 (60 X 60 Cm)

Tabel 2. Kapasitas Daya Dukung Geser Kolom Eksisting

Dari Tabel 2. terlihat bahwa tulangan geser yang terpasang, mampu menahan gaya geser yang diakibatkan oleh gaya luar. Hal ini terlihat dari tulangan geser yang terpasang lebih besar dari tulangan geser yang dibutuhkan, serta tidak ada elemen kolom yang mengalami kegagalan geser.

\subsection{Analisa Dinding}

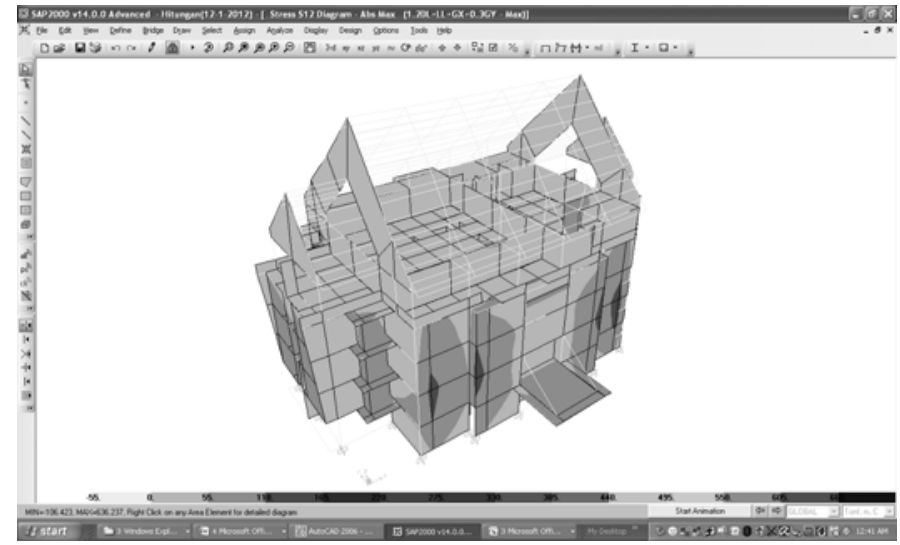

Gambar 3. Tegangan Geser Dinding Sejajar Bidang, Akibat Berat Sendiri dan Gempa $(100 \% \mathrm{X}+30 \% \mathrm{Y})$

\section{6 | J URNAL REKAYASA SIPIL}


Maksimum tegangan geser dinding yang diizinkan $=2 \mathrm{~kg} / \mathrm{cm}^{2}$. Dari Gambar 3, terlihat ada beberapa bagian dinding dengan tegangan geser lebih besar dari $2 \mathrm{~kg} / \mathrm{cm}^{2}$ dan ini mengindikasikan dinding tersebut mengalami keruntuhan akibat beban gempa.

\subsection{Kinerja Batas Layan}

Kinerja batas layan struktur gedung ditentukan oleh simpangan antar-tingkat akibat pengaruh Gempa Rencana, yaitu untuk membatasi terjadinya pelelehan baja dan peretakan beton yang berlebihan, di samping untuk mencegah kerusakan non-struktur dan ketidaknyamanan penghuni. Simpangan antar-tingkat ini harus dihitung dari simpangan struktur gedung tersebut akibat pengaruh Gempa Nominal yang telah dibagi Faktor Skala. Untuk memenuhi persyaratan kinerja batas layan struktur gedung, dalam segala hal simpangan antar-tingkat yang dihitung dari simpangan struktur tidak boleh melampaui 0,03/R kali tinggi tingkat yang bersangkutan atau 30 $\mathrm{mm}$, gunakan nilai terkecil dari 0,03/R kali tinggi tingkat atau $30 \mathrm{~mm}$ sebagai simpangan yang diizinkan. Nilai simpangan antar tingkat massa gedung akibat gempa arah $-\mathrm{x}$ dan y dapat dilihat pada Tabel 3 dan 4.

Tabel 3. Simpangan Antar Tingkat Massa Gedung Akibat Gempa Arah - x

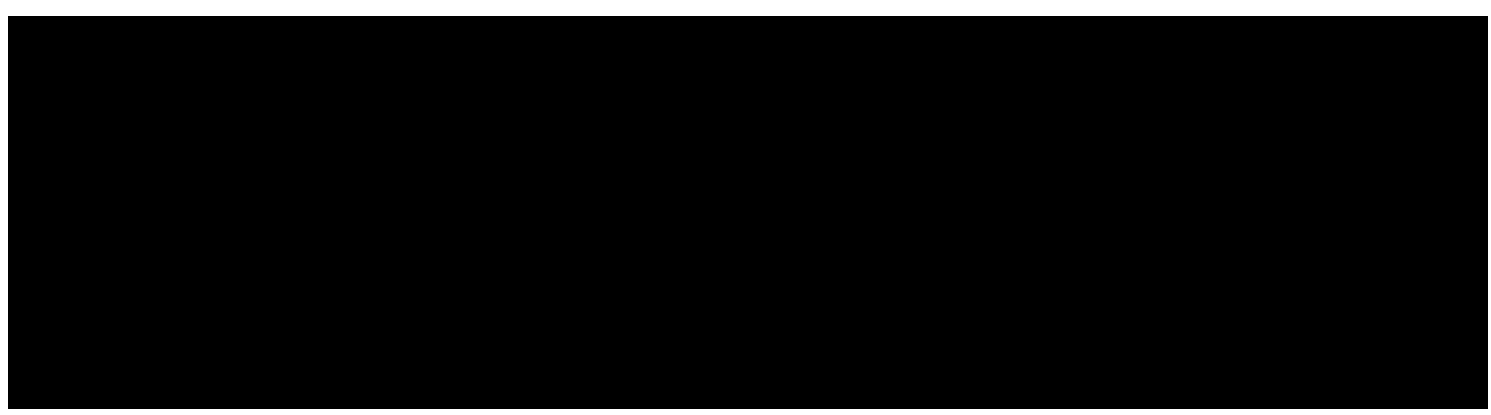

Tabel 4. Simpangan Antar Tingkat Massa Gedung Akibat Gempa Arah - y

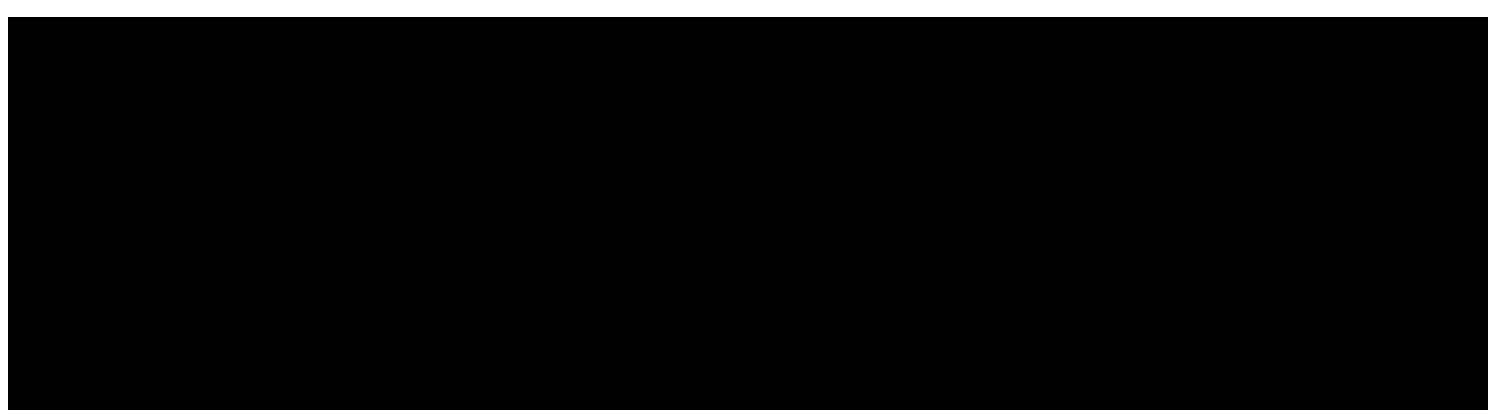

\subsection{Tegangan Geser Dinding}

Kemampuan dinding dalam menahan beban digambarkan oleh besarnya tegangan geser yang bekerja pada dinding, baik oleh beban lateral maupun beban akibat tekanan angin. Pada analisa gedung BPKP, tegangan geser dinding adalah seperti pada Gambar 4. Pada gambar tersebut terdapat bagian-bagian dari dinding bata yang mengalami tegangan geser akibat gempa melebihi tegangan geser bata yang diizinkan. 


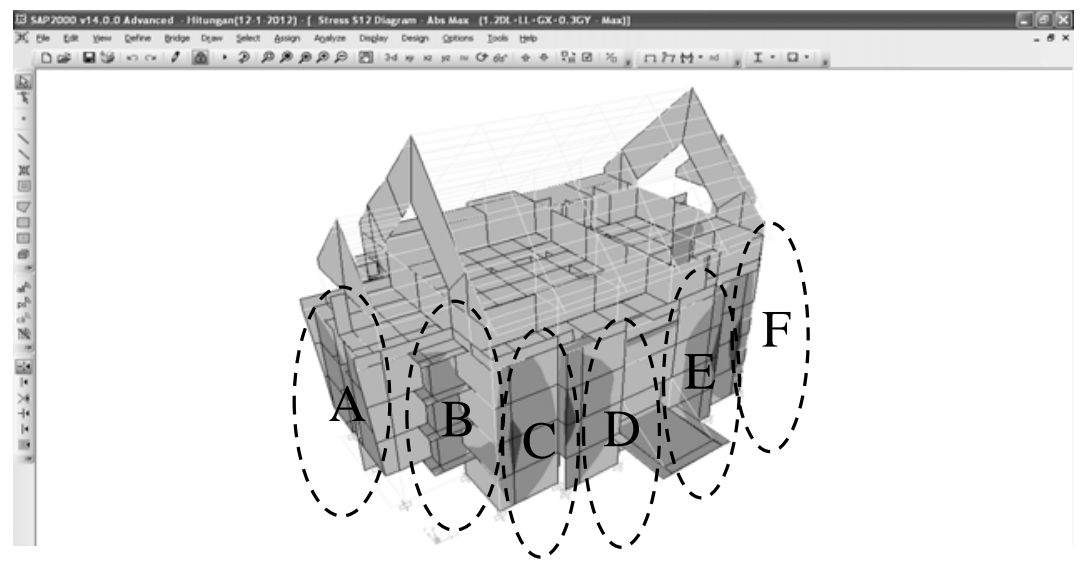

Gambar 4. Tegangan Geser Dinding Sejajar Bidang Akibat Gempa

Dari Gambar 4., terlihat bahwa dinding gedung BPKP mengalami keruntuhan pada as 1-A s/d 1$\mathrm{B}$, as 1-C s/d 1-D, as 1-E s/d 1-F dan as 1-F s/d 1-G pada lantai $1 \mathrm{~s} / \mathrm{d}$ 4, hal ini disebabkan oleh :

1. Tegangan geser maksimum sejajar bidang yang terjadi akibat gempa lebih besar daripada tegangan izin geser. Sesuai Gambar 4. pada area E, F, G dan H tegangan geser yang terjadi adalah $11 \mathrm{~kg} / \mathrm{cm}^{2}$. Sementara, material dinding pada gedung BPKP berupa bata dengan tegangan geser izin sebesar $2 \mathrm{~kg} / \mathrm{cm}^{2}$.

2. Struktur pasangan bata menyebabkan bobot mati struktur besar, kekuatan dan daktilitasnya terhadap beban lateral (gempa) menjadi sangat rendah, sehingga mudah mengalami keruntuhan.

3. Pemasangan dinding bata bagian luar gedung terdiri dari dua lapis, dengan sistem pemasangan yang berbeda pada masing-masing lapisnya.

a. Lapisan dinding bagian dalam menggunakan kolom dan balok praktis sebagai pengakunya.

b. Lapisan dinding bagian luar dipasang tanpa menggunakan kolom dan balok praktis, hal ini menyebabkan lapisan dinding bagian luar sangat rentan mengalami keruntuhan ketika ada beban lateral.

4. Struktur beton yang dikombinasikan dengan pasangan bata sebagai pengisi, tetapi tidak dilengkapi batang/besi/jangkar yang mengikat kolom ke dinding bata. Bobot mati pasangan yang besar menghasilkan gaya inersia lateral yang besar, menyebabkan pasangan bata mengalami keruntuhan.

\subsection{Diagram Interaksi Kolom}

Dari hasil analisa struktur dan investigasi lapangan, kerusakan yang terjadi umumnya berada di lantai 3, kerusakan tersebut meliputi terlepasnya selimut beton pada kaki kolom dan kerusakan beton pada ujung kolom. Diagram interaksi pada kolom lantai 3 dapat dilihat pada Gambar 5 dan Gambar 6.

\section{8 | JURNAL REKAYASA SIPIL}




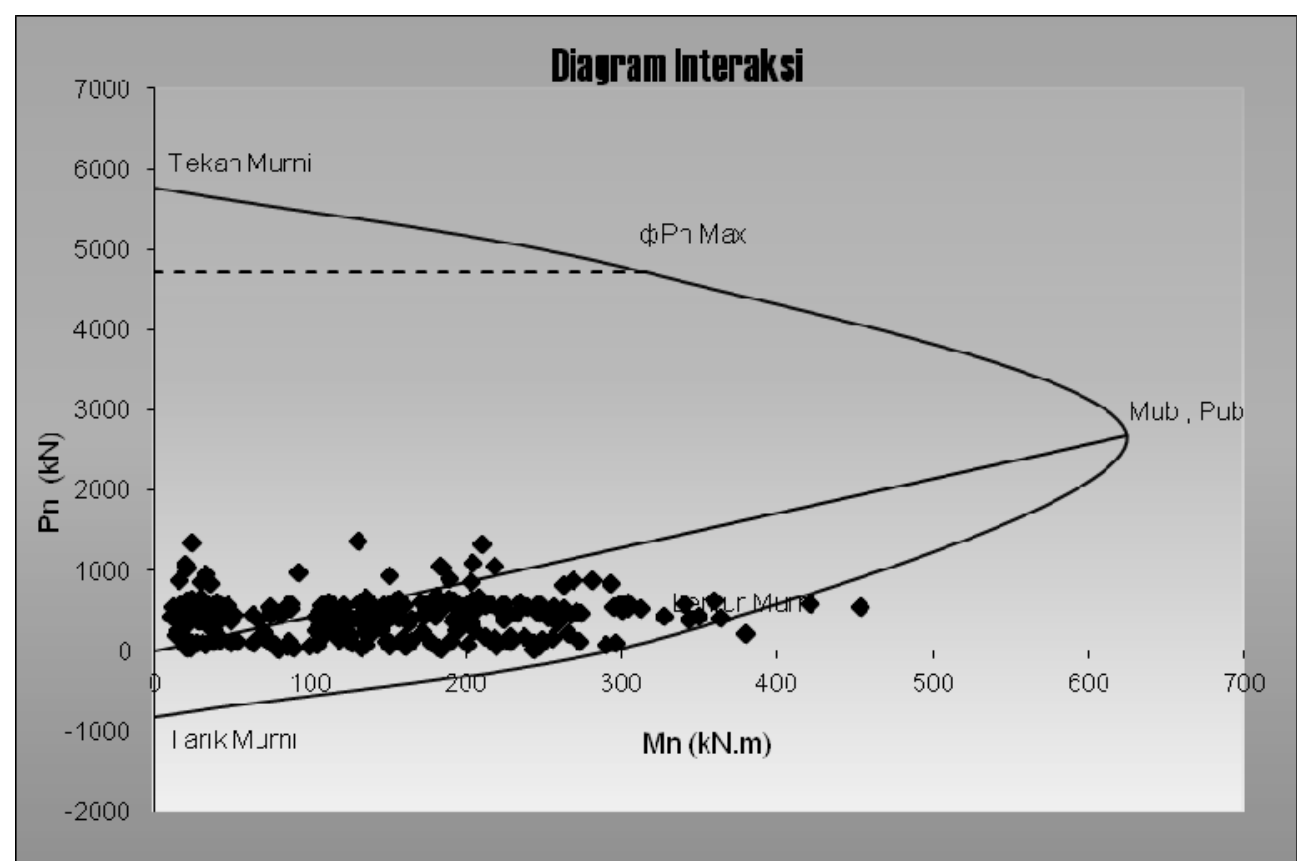

Gambar 5. Diagram Interaksi Kolom Eksternal Lantai 3

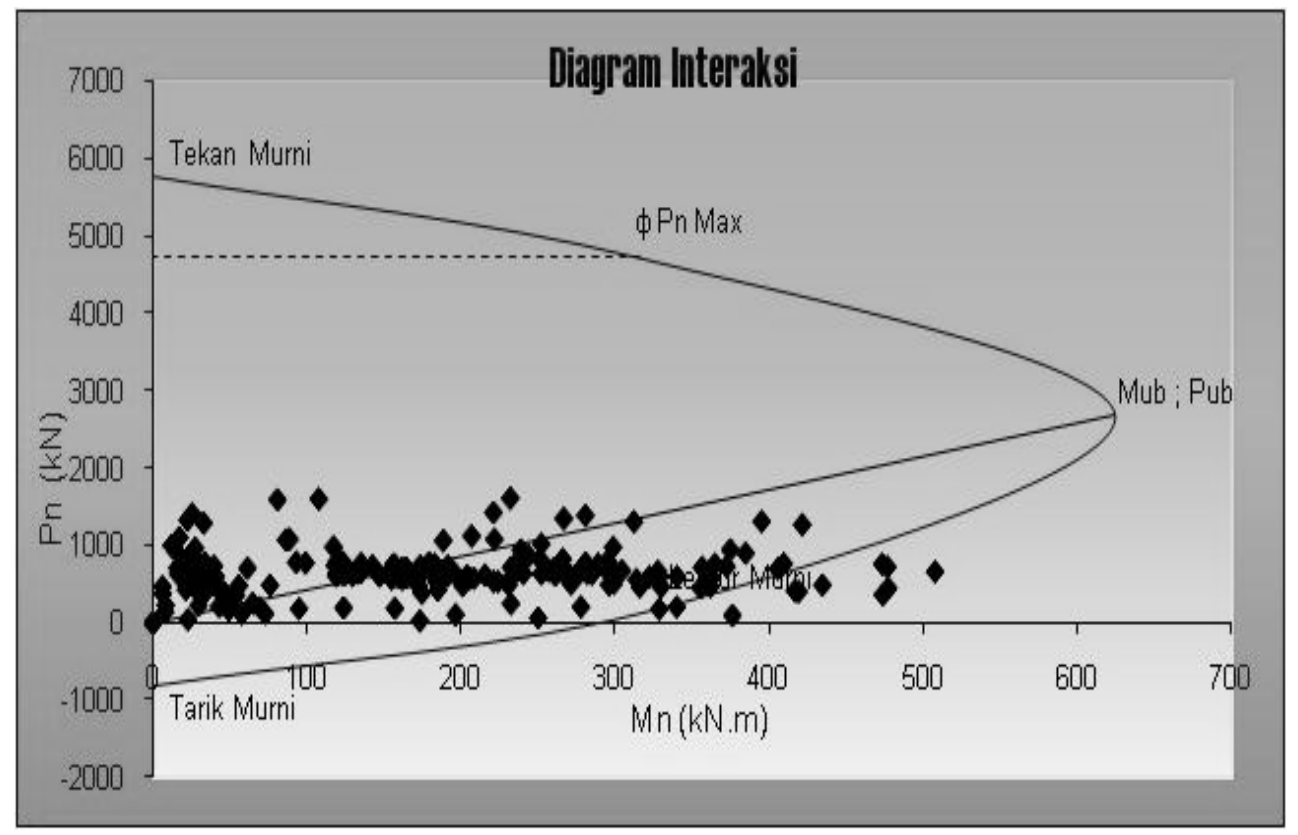

Gambar 6. Diagram Interaksi Kolom Internal Lantai 3 


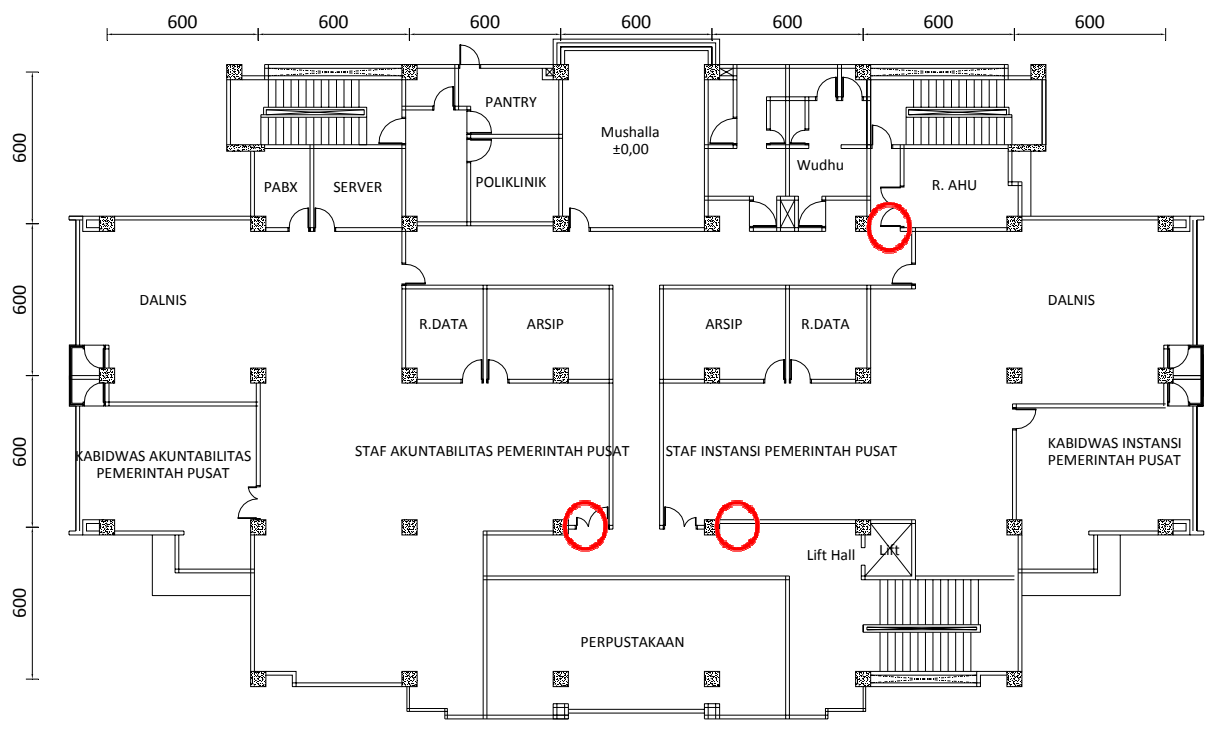

Gambar 7. Denah kerusakan kolom lantai 3

Kolom lantai 3 pada gedung BPKP mengalami kerusakan-kerusakan (Gambar 7.) karena :

1. Tulangan lentur yang terpasang telah mengalami leleh, hal ini terlihat dari kondisi tulangan yang bengkok. Maka dapat diartikan bahwa kolom tersebut mengalami kegagalan lentur.

2. Sengkang kolom terlepas, hal ini dimungkinkan jika sengkang yang terpasang untuk menahan gaya geser pada kolom tersebut lebih kecil dari yang dibutuhkan (buckling failure). Sengkang kolom yang dibutuhkan untuk kolom lantai 2 adalah Ø8 - $200 \mathrm{~mm}$, sementara sengkang yang terpasang adalah Ø10 - $200 \mathrm{~mm}$. Sehingga seharusnya sengkang tersebut tidak mengalami kerusakan. Jadi, terlepasnya sengkang pada kolom tersebut lebih disebabkan oleh lelehnya tulangan lentur dan pecahnya beton akibat kerusakan lentur yang terjadi.

\subsection{Selimut Beton}

Dari beberapa kolom yang mengalami kerusakan, terindikasi bahwa penyebab kerusakan kolom tidak hanya diakibatkan oleh kegagalan lentur ataupun geser, tetapi juga disebabkan oleh ketebalan selimut beton lebih kecil dari ketebalan minimum yang disyaratkan pada Peraturan Tata Cara Perhitungan Struktur Beton Untuk Bangunan Gedung SNI 03-2847-2002.

\subsection{Joint Balok Kolom}

Kerusakan joint pada balok kolom, terlihat dari lepasnya selimut beton pada kolom dan lepasnya sambungan balok ke kolom yang terjadi di lantai 3. Berdasarkan hasil investigasi lapangan, terlihat bahwa :

1. Detail tulangan yang tidak memenuhi syarat "kesatuan komponen”, yaitu ujung baja tulangan balok tidak terjangkar cukup dalam kekolom. Demikian juga ujung tulangan kolom tidak terjangkar cukup panjang ke balok, join balok kolom tidak dilengkapi dengan sengkang penahan geser dan sengkang inti-join.

2. Lemahnya sambungan join balok-kolom karena detail tulangan join tidak dilengkapi dengan sengkang penahan gaya geser.

3. Penyelesaian detail join komponen beton yang tidak sesuai dengan ketentuan bangunan tahan gempa.

\section{0 | JURNAL REKAYASA SIPIL}




\subsection{Perbaikan dan Perkuatan Gedung}

Pada bagian ini dibahas rekomendasi perbaikan struktur dan non struktur bangunan. Perbaikan struktur pada bagian ini didasarkan kepada jenis kerusakan yang terjadi. Hasil analisa yang telah dilakukan pada elemen struktur balok, kolom dan elemen non struktur seperti dinding adalah sebagai berikut:

1. Kolom bangunan mengalami kerusakan lentur pada lantai 3, terutama pada ujung kolom.

2. Perhitungan analisa kapasitas penampang kolom lantai 3 menunjukkan hasil tulangan utama kolom yang terpasang tidak mampu memikul beban yang akan bekerja padanya.

3. Kerusakan pada dinding diakibatkan karena tidak adanya kekangan pada dinding, baik oleh kolom praktis maupun tidak adanya penjangkaran bata ke kolom.

\subsection{Perbaikan Struktur}

Metoda perbaikan dengan beberapa kondisi kerusakan yang dialami struktur bangunan :

a. Retak pada beton kolom

Metode injeksi dengan material pasta semen yang dicampur dengan expanding agent serta latex atau hanya melakukan sealing dengan material polymer mortar atau polyurethane sealant.

b. Beton kolom terlepas sehingga tulangan kelihatan

Jika kapasitas tulangan masih memadai, material (beton) pengganti minimal harus sesuai dengan mutu beton rencana gedung atau dengan material yang mutunya lebih baik. Pada saat pelaksanaan harus dipastikan bahwa cetakan beton dan skor-skor sudah dipersiapkan dan terpasang dengan baik.

c. Beton kolom hancur/rusak berat

Langkah-langkah yang dapat dilakukan dalam memperbaiki kolom yang hancur/rusak berat :

1. Kedua sisi kolom ditopang dengan menggunakan support.

2. Seluruh beton kolom dikupas dan diperbaiki detail penulangannya.

3. Pasang bekisting kolom dan pada bagian atas bekisting (pada balok) dilobangi untuk melakukan pengecoran. Lakukan pengecoran pada kolom dengan menggunakan beton ready mix $\mathrm{K}-300$.

4. Bekisting kolom dibuka setelah beton cukup umur.

\subsection{Perbaikan Non-Struktur}

Kerusakan dinding banyak terjadi pada bagian luar gedung, teruatama pada bagian depan. Hal ini terjadi karena tegangan dinding yang terjadi akibat beban gempa (mendekati $11 \mathrm{~kg} / \mathrm{cm}^{2}$ ) lebih besar daripada tegangan izin bata $\left(2 \mathrm{~kg} / \mathrm{cm}^{2}\right)$.

Untuk elemen bangunan yang rusak ringan, dapat dilakukan perbaikan dengan cara berikut:

1. Dinding retak diagonal, karena geser atau retak vertikal karena lentur.

a. Plesteran lama di sekitar retak dikupas, lalu retak diisi dengan adukan semen pasir (perbandingan 1 semen : 3 pasir).

b. Setelah celah rapat, kemudian dinding diplester kembali dengan campuran spesi 1 semen : 3 pasir.

c. Untuk retak yang besar $(>0,6 \mathrm{~cm})$ setelah di isi dengan adukan semen pasir, pada bagian bekas retakan.

2. Dinding hancur

Dilakukan pemasangan dinding baru lengkap dengan angkur-angkur setiap 6 lapis bata dengan panjang angkur minimum $30 \mathrm{~cm}$. Pada bidang dinding $>9 \mathrm{~m}^{2}$; dipasang elemen perkuatan kolom praktis dan balok pinggang (tulangan $4 \varnothing 10 \mathrm{~mm}$, sengkang Ø8-150 mm)

VOLUME 7 NO.2, OKTOBER 2011 | 11 


\subsection{Perkuatan Struktur Menggunakan Dinding Geser}

Untuk menambah kekakuan struktur sehingga mampu menahan gaya gempa dengan periode ulang 500 tahun sesuai dengan Peta Hazard Gempa Indonesia Tahun 2010 (Badan Penelitian dan Pengembangan Kementrian Pekerjaan Umum, 2010), maka gedung BPKP diberi perkuatan berupa penambahan dinding geser pada keempat sudut gedung.

Dinding geser dipakai dalam perkuatan struktur Gedung BPKP dengan pertimbangan sebagai berikut :

1. Dinding geser efektif dalam menahan beban lateral.

2. Dalam pelaksanaan konstruksinya, pemasangan dinding geser lebih mudah dari metoda perkuatan struktur lainnya, seperti bracing, jacketing dan lain-lain.

3. Dinding geser dapat langsung difungsikan sebagai pengganti dinding yang mengalami kerusakan pasca gempa.

4. Penggunaan dinding geser tidak mengubah bentuk arsitektur gedung secara signifikan.

\subsection{Perkuatan Struktur Dengan Metoda Jacketing}

Jacketing adalah salah satu perkuatan struktur yang digunakan kepada kolom bangunan. Jacketing bertujuan untuk memperbesar penampang kolom, sehingga penampang kolom menjadi besar dari pada sebelumnya sehingga kekuatan geser beton jadi meningkat. Perkuatan kolom dengan jacketing efektif untuk meningkatkan kekuatan geser kolom dan aksial kolom namun kurang efektif untuk meningkatkan kekuatan lentur kolom.

Jacketing dilakukan dengan memperbesar penampang kolom dan menambah tulangan lentur dan geser kolom di keliling kolom yang lama. Penambahan dilakukan pada masing-masing sisi kolom sebesar $10 \mathrm{~cm}$, tulangan lentur masing-masing kolom ditambah 8 batang dengan diameter tulangan sama dengan diameter tulangan eksisting. Untuk sengkang ditambah dengan besi diameter $12 \mathrm{~mm}$ spasi $10 \mathrm{~cm}$.

\subsection{Perbandingan Perpindahan Maksimum Sebelum dan Sesudah Perkuatan}

Simpangan sebelum dan sesudah perbaikan mempunyai pola yang sama (Gambar 8 dan 9), baik simpangan antar tingkat pada arah x (utara bangunan) maupun simpangan antar tingkat pada arah y (barat bangunan). Dari hasil analisa diperoleh simpangan antar tingkat sesudah perkuatan lebih kecil dari simpangan antar tingkat sebelum perbaikan. Hal ini mengindikasikan bahwa kinerja struktur akan lebih baik setelah kolom diperbaiki dan diberi dinding geser maupun diperbesar penampangnya. Simpangan diperoleh dari titik kontrol pusat massa gedung berada pada As 2-D.

\section{Perbandingan Perpindahan Maksimum Sebelum dan Sesudah Perkuatan}

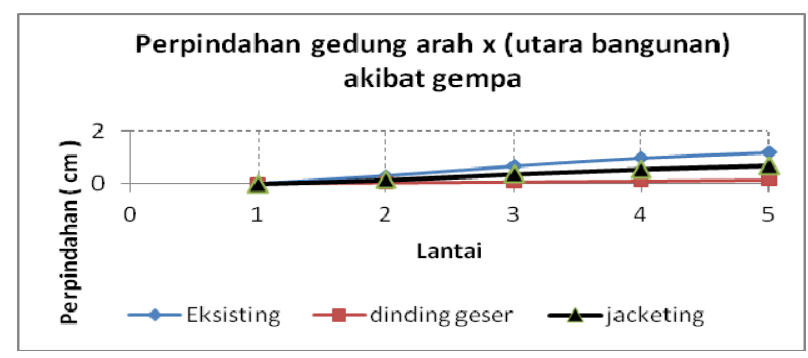

Gambar 8. Perpindahan Gedung Arah X (Utara Bangunan) Akibat Gaya Gempa

\section{2 | JURNAL REKAYASA SIPIL}




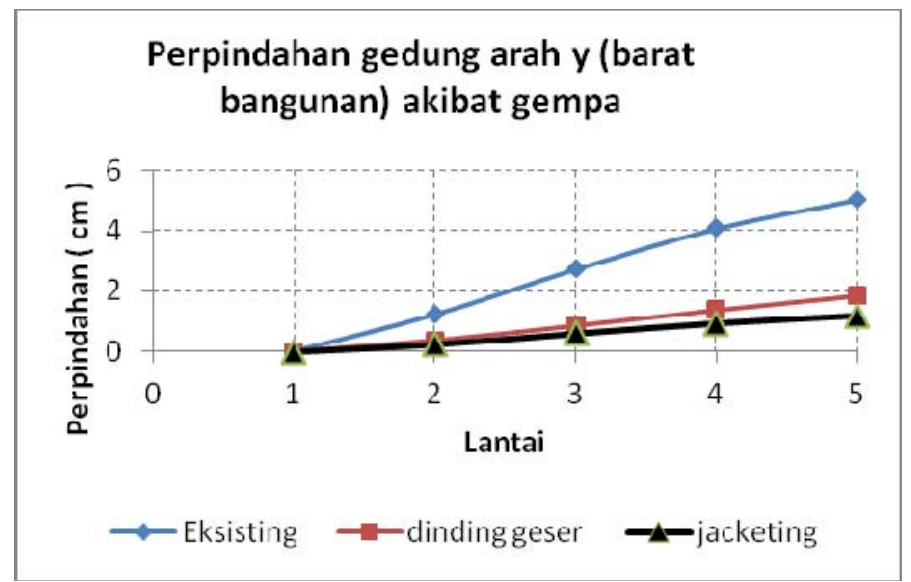

Gambar 9. Perpindahan Gedung Arah Y (Barat Bangunan) Akibat Gaya Gempa

Perbandingan Gaya Lentur Maksimum Pada Kolom Sebelum Dan Sesudah Perkuatan

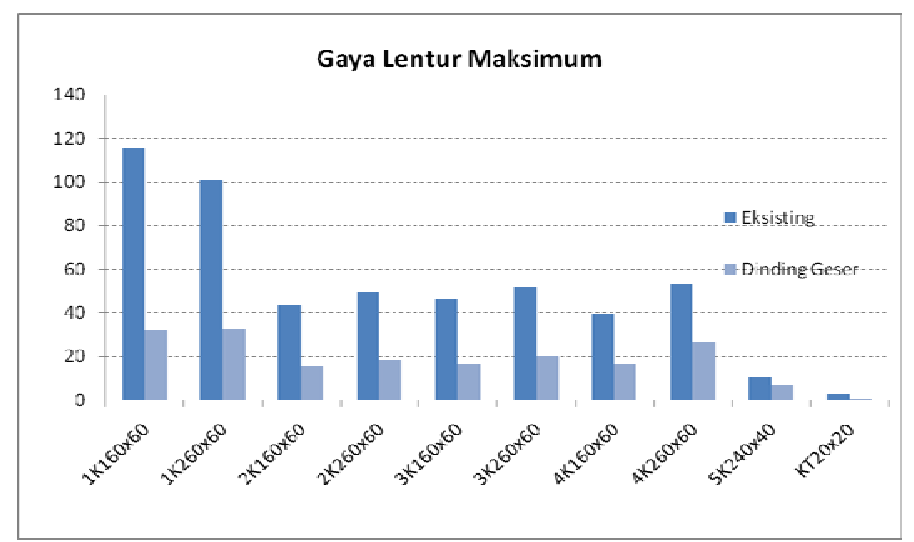

Gambar 10. Perbandingan Gaya Lentur Maksimum Kolom Dengan Penambahan Dinding Geser

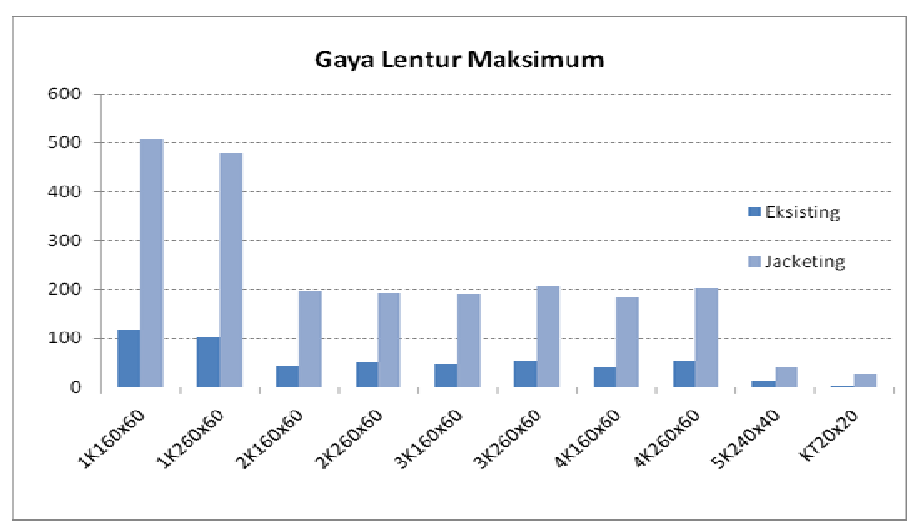

Gambar 11. Perbandingan Gaya Lentur Maksimum Kolom Setelah Perkuatan Dengan Metode Jacketing 
Dari Gambar 10 dan 11. terlihat penambahan dinding geser maupun perkuatan dengan metode jacketing pada struktur gedung, mempengaruhi perilaku gedung secara signifikan. Dari Gambar 3 dan 4. Terlihat bahwa perpindahan struktur gedung setelah diberi dinding geser berkurang hingga $80 \%$ dibandingkan dengan kondisi eksisting. Hal yang sama terlihat pada perkuatan struktur menggunakan jacketing yang mereduksi perpindahan struktur hingga $45 \%$ dibandingkan dengan kondisi eksisting. Gaya lentur kolom setelah dilakukan perkuatan dengan dinding geser juga tereduksi sampai 60\% dari gaya lentur kolom pada kondisi eksisting.

\section{KESIMPULAN}

Dari pembahasan tentang Gedung BPKP, baik bedasarkan data investigasi lapangan maupun setelah dilakukan analisa ulang terhadap struktur gedung BPKP, diperoleh kesimpulan sebagai berikut :

1. Kerusakan struktur Gedung BPKP terkonsentrasi pada kerusakan kolom, terutama pada ujungujung kolom lantai 3 umumnya disebabkan oleh kegagalan lentur pada kolom yang diakibatkan oleh gaya gempa.

2. Kerusakan non-struktur pada Gedung BPKP terutama kerusakan dinding, umumnya disebabkan oleh tidak adanya balok dan kolom praktis sebagai pengaku dinding serta tidak adanya angkur dari kolom ke bata, sehingga jika terjadi gaya lateral oleh gempa, dinding akan mudah mengalami kerusakan.

3. Alternatif perbaikan yang bisa dilakukan seperti metoda injeksi pada kolom yang retak, metoda grouting pada kolom yang betonnya terlepas, serta penambahan kolom dan balok praktis pada dinding yang mengalami kerusakan.

4. Perkuatan dengan dinding geser sangat efektif dalam menurunkan nilai perpindahan gedung hingga 80\% (arah x/utara bangunan) dibandingkan dengan kondisi eksisting maupun mereduksi gaya-gaya dalam yang terjadi pada elemen-elemen struktur terutama yang diakibatkan oleh gaya lateral.

5. Perkuatan struktur menggunakan metode jacketing hanya mampu mereduksi perpindahan struktur hingga 45\% (arah x/utara bangunan) dibandingkan dengan kondisi eksisting.

\section{DAFTAR KEPUSTAKAAN}

Badan Penelitian dan Pengembangan Kementrian Pekerjaan Umum, (2010), “Peta Hazard Gempa Indonesia 2010”, Jakarta.

Departemen Pekerjaan Umum, (1987), "Perencanaan Ketahanan Gempa Untuk Rumah Dan Gedung".

Dewobroto, Wiryanto, (2006), "Evaluasi Kinerja Badan Penelitian dan Pengembangan Kementrian Pekerjaan Umum Bangunan Baja Tahan Gempa dengan SAP2000”, Jurnal Teknik Sipil Unika Soegijapranata, Semarang.

Peraturan Pembebanan Indonesia Untuk Gedung (PPIUG), (1983), “Direktorat Penyelidikan Masalah Bangunan”, Bandung.

SNI 03-1726-2002,(2002), "Standar Perencanaan Ketahanan Gempa untuk Struktur Bangunan Gedung”. Badan Standarisasi Nasional, Puslitbang Pemukiman, Bandung.

SNI 03-2847-2002,(2002), “Tata cara Perhitungan Struktur Beton untuk Bangunan Gedung”, Badan Standarisasi Nasional, Puslitbang Pemukiman, Bandung.

\section{4 | JURNAL REKAYASA SIPIL}

